\title{
Is there a Connection between Maternal Hypothyroidism and Developing Autism Spectrum Disorders?
}

\author{
Ahmed R.G* \\ Division of Anatomy and Embryology, Zoology Department, Faculty of Science, Beni-Suef University, Beni- \\ Suef, Egypt
}

*Corresponding Author: Ahmed R.G, Division of Anatomy and Embryology, Zoology Department, Faculty of Science, Beni-Suef University, Beni-Suef, Egypt, Email: ahmedragab08@gmail.com

\section{LETTER TO EDITOR}

The activities of maternal thyroid hormones (THs) can induce important actions on the neural development, synaptogenesis, and normal brain development during the perinatal period (El-bakry et al., 2010; Ahmed, 2011, 2012a,b, 2013, 2014, 2015a-c, 2016a-d, 2017a-u \& 2018a-c; Ahmed et al., 2010, 2013a,b, 2014, 2015a,b \& 2018a,b; Ahmed and Incerpi, 2013; Van Hercket al., 2013; Ahmed and ElGareib, 2014,Incerpi et al., 2014; Candelotti et al., 2015; De Vito et al., 2015; El-Ghareeb et al., 2016; Ahmed and El-Gareib, 2017).Several authors mentioned that autism spectrum disorders (ASD)(group of neuropsychiatric disorders) is characterized by the alterations and impairments in the neuroanatomical, morphological, neuro chemical, movements, social, and language interactions in different brain regions such as the basal ganglia, corpus callosum, cerebellum, and limbic system (Rosenberg et al., 2009; Anney et al., 2010; Sajdel-Sulkowska et al., 2010). In addition, Roman (2007) and King (2011) observed that the maternal hypothyroidism during the gestation could disrupt the neural development and functions, and increase the risk of ASD. In addition, Ahmed et al. (2008) and Melancia et al. (2017) postulated that maternal thyroid hypothyroidism increased the risk of several neonatal neuro developmental disorders. These abnormalities may be probably due to the following: (1) the diminution in the activity of deiodinase 2 (D2) (reduced the conversion of thyroxine (T4) to 3,5,3'-triodothyronine (T3)) (Davis et al., 2008); and (2) the abnormal metabolism in the intra cerebellar TH due to the elevation in the activity of D3 in the cerebrospinal fluid (CSF) could increase the levels of reverse T3(rT3) and the ratio of rT3:T4 (Sampaolo et al., 2005).More interestingly, the levels of free rT3 and T4 in the CSF were augmented during the endogenous depression (Kirkegaard and Faber, 1991).On the other hand, hypothyroidism can alter the expression of genes in different brain regions (Van Hercket al., 2013). A systemic hypothyroidism in developing rat cerebellum can disrupt the migration of several cerebellar cells (granule and Purkinje cells) inducing several alterations in the gene expressions (Miyata et al., 2010). Reelin gene is regulated by the $\mathrm{T} 3$ in fetal brain, is responsible for the migration of neuronal cells, and is implicated in the developing ASD (Fatemi et al., 2005; Sampaolo et al., 2005; Verhoelst et al., 2005; Davis et al., 2008; Miyata et al., 2010). However, the associations between the maternal thyroid deficiency and the onset of neonatal ASD are still debated.

From the connection between the aforementioned explanations and the current view, it can be concluded that the developing autism due to the maternal hypothyroidism may be disrupted the activities of D2 and D3, the levels of T4 and T3, and the gene and thyroid receptors (TRs) expression resulting in a region specific $\mathrm{T} 3$ deficiency in the neonatal brain. These maternal disorders may impair the social, learning, and economic interactions for the neonates. Future studies are warranted to explore the developmental and molecular interactions of maternal thyroid dysfunction (thyroid stimulating hormone (TSH), T4 and T3) and autism development. Other studies are required to determine the activities of Ds and gene expression in ASD. 


\section{REFERENCES}

[1] Ahmed, O.M., Abd El-Tawab, S.M., Ahmed, R.G., 2010. Effects of experimentally induced maternal hypothyroidism and hyperthyroidism on the development of rat offspring: I- The development of the thyroid hormonesneurotransmitters and adenosinergic system interactions. Int. J. Dev. Neurosci. 28, 437-454.

[2] Ahmed, O.M., Abd El-Tawab, S.M.,Ahmed, R.G., 2010. Effects of experimentally induced maternal hypothyroidism and hyperthyroidism on the development of rat offspring: I- The development of the thyroid hormonesneurotransmitters and adenosinergic system interactions. Int. J. Dev. Neurosci. 28, 437-454.

[3] Ahmed, O.M., Ahmed, R.G., 2012. Hypothyroidism. In A New Look At Hypothyroidism. Dr. D. Springer (Ed.), ISBN: 978-953-51-0020-1), In Tech Open Access Publisher, Chapter 1, pp. 1-20.

[4] Ahmed, O.M., Ahmed, R.G., El-Gareib, A.W., El-Bakry, A.M., Abd El-Tawaba, S.M., 2012. Effects of experimentally induced maternal hypothyroidism and hyperthyroidism on the development of rat offspring: II-The developmental pattern of neurons in relation to oxidative stress and antioxidant defense system. Int. J. Dev. Neurosci. 30, 517-537.

[5] Ahmed, O.M., El-Gareib, A.W., El-bakry, A.M., Abd El-Tawab, S.M., Ahmed, R.G., 2008. Thyroid hormones states and brain development interactions. Int. J. Dev. Neurosci. 26(2), 147-209. Review.

[6] Ahmed, R.G., 2011. Perinatal 2, 3, 7, 8tetrachlorodibenzo-p-dioxin exposure alters developmental neuroendocrine system. Food Chem. Toxicology, 49, 1276-1284.

[7] Ahmed, R.G., 2012a. Maternal-newborn thyroid dysfunction. In the Developmental Neuroendocrinology, pp. 1-369. Ed R.G. Ahmed. Germany: LAP LAMBERT Academic Publishing GmbH \& Co KG.

[8] Ahmed, R.G., 2012b. Maternal-fetal thyroid interactions, Thyroid Hormone, Dr. N.K. Agrawal (Ed.), ISBN: 978-953-51-0678-4, In Tech Open Access Publisher, Chapter 5, pp. 125-156.

[9] Ahmed, R.G., 2013. Early weaning PCB 95 exposure alters the neonatal endocrine system: thyroid adipokine dysfunction. J. Endocrinol. 219 (3), 205-215.

[10] Ahmed, R.G., 2014. Editorial: Do PCBs modify the thyroid-adipokine axis during development? Annals Thyroid Res. 1(1), 11-12.

[11] Ahmed, R.G., 2015a. Chapter 1: Hypothyroidism and brain development. In advances in hypothyroidism treatment. Avid Science Borsigstr.9, 10115 Berlin, Berlin, Germany. Avid Science Publications level 6,
Melange Towers, Wing a, Hitec City, Hyderabad, Telangana, India. pp. 1-40.

[12] Ahmed, R.G., 2015b. Hypothyroidism and brain developmental players. Thyroid Research J. 8(2), 1-12.

[13] Ahmed, R.G., 2015c. Editorials and Commentary: Maternofetal thyroid action and brain development. J. of Advances in Biology; 7(1), 1207-1213.

[14] Ahmed, R.G., 2016a. Gestational dexamethasone alters fetal neuroendocrine axis. Toxicology Letters, 258, 46-54.

[15] Ahmed, R.G., 2016b. Neonatal polychlorinated biphenyls-induced endocrine dysfunction. Ann. Thyroid. Res. 2 (1), 34-35.

[16] Ahmed, R.G., 2016c. Maternal iodine deficiency and brain disorders. Endocrinol. Metab.Syndr.5, 223.http://dx.doi.org/ 10.4172/ 2161-1017.1000223.

[17] Ahmed, R.G., 2016d. Maternal bisphenol A alters fetal endocrine system: Thyroid adipokine dysfunction. Food Chem. Toxicology, 95, 168-174.

[18] Ahmed, R.G.,2017a. Developmental thyroid diseases and GABAergic dysfunction. EC Neurology 8.1, 02-04.

[19] Ahmed, R.G., 2017b. Hyperthyroidism and developmental dysfunction. Arch Med. 9, 4.

[20] Ahmed, R.G.,2017c. Anti-thyroid drugs may be at higher risk for perinatal thyroid disease. EC Pharmacology and Toxicology 4.4, 140-142.

[21] Ahmed, R.G.,2017d. Perinatal hypothyroidism and cytoskeleton dysfunction. Endocrinol Metab Syndr 6, 271.doi:10.4172/21611017.1000271

[22] Ahmed, R.G., 2017e. Developmental thyroid diseases and monoaminergic dysfunction. Advances in Applied Science Research 8(3), 01-10.

[23] Ahmed, R.G.,2017f. Hypothyroidism and brain development. J. Anim Res Nutr.2(2), 13.

[24] Ahmed, R.G.,2017g. Antiepileptic drugs and developmental neuroendocrine dysfunction: Every why has A Wherefore. Arch Med 9(6), 2.

[25] Ahmed, R.G.,2017h. Gestational prooxidantantioxidant imbalance may be at higher risk for postpartum thyroid disease. Endocrinol Metab Syndr 6, 279. doi:10.4172/2161-1017.1000279.

[26] Ahmed, R.G.,2017i. Synergistic actions of thyroid-adipokines axis during development. Endocrinol Metab Syndr 6, 280.doi:10.4172/21611017.1000280.

[27] Ahmed, R.G.,2017j. Thyroid-insulin dysfunction during development. International Journal of Research Studies in Zoology 3(4), 73-75. DOI: http://dx.doi.org/10.20431/2454-941X.0304010 
[28] Ahmed, R.G., 2017k. Developmental thyroid diseases and cholinergic imbalance. International Journal of Research Studies in Zoology 3(4), 7072. DOI: http://dx.doi.org/10.20431/2454-941X. 0304009.

[29] Ahmed, R.G., 20171. Thyroid diseases and developmental adenosinergic imbalance. Int $\mathbf{J}$ ClinEndocrinol 1(2), 053-055.

[30] Ahmed, R.G., 2017m.Maternal anticancer drugs and fetal neuroendocrine dysfunction in experimental animals. Endocrinol MetabSyndr 6, 281.doi:10.4172/2161-1017.1000281.

[31] Ahmed, R.G., 2017n. Letter: Gestational dexamethasone may be at higher risk for thyroid disease developing peripartum. Open Journal of Biomedical \& Life Sciences (Ojbili) 3(2), 01-06.

[32] Ahmed, R.G.,2017o. Deiodinases and developmental hypothyroidism. EC Nutrition $11.5,183-185$

[33] Ahmed, R.G.,2017p. Maternofetal thyroid hormones and risk of diabetes. Int. J. of Res. Studies in Medical and Health Sciences 2(10), $18-21$.

[34] Ahmed, R.G., 2017r.Association between hypothyroidism and renal dysfunctions. International Journal of Research Studies in Medical and Health Sciences 2(11), 1-4.

[35] Ahmed, R.G., 2017s.Maternal hypothyroidism and lung dysfunction. International Journal of Research Studies in Medical and Health Sciences 2(11), 8-11.

[36] Ahmed, R.G., 2017t.Endocrine disruptors; possible mechanisms for inducing developmental disorders. International journal of basic science in medicine (IJBSM) 2(4), XX-XX. (in press)

[37] Ahmed, R.G., 2017u.Maternal thyroid hormones trajectories and neonatal behavioral disorders. ARC Journal of Diabetes and Endocrinology 3(2), 18-21.

[38] Ahmed, R.G.,2018a. Maternal hypothyroidism and neonatal testicular dysfunction. International Journal of Research Studies in Medical and Health Sciences 3(1), 8-12.

[39] Ahmed, R.G., 2018b. Maternal thyroid disorders and bone maldevelopment: Are you ready to take risks for your offspring? J Pharma PharmaSci (JPPS) in press. DOI: 10.29011/ 2574-7711. 100058.

[40] Ahmed, R.G., 2018c. Non-genomic actions of thyroid hormones during development. App ClinPharmacolToxicol: ACPT-108. DOI: 10.29011/ACPT-109. 100008.

[41] Ahmed, R.G., Abdel-Latif, M., Ahmed F., 2015a.Protective effects of GM-CSF in experimental neonatal hypothyroidism.
International Immunopharmacology 29, 538543.

[42] Ahmed, R.G., Abdel-Latif, M., Mahdi, E., ElNesr, K., 2015b. Immune stimulation improves endocrine and neural fetal outcomes in a model of maternofetal thyrotoxicosis. Int. Immunopharmacol. 29, 714-721.

[43] Ahmed, R.G., Davis, P.J., Davis, F.B., De Vito, P., Farias, R.N., Luly, P., Pedersen, J.Z., Incerpi, S., 2013a. Nongenomic actions of thyroid hormones: from basic research to clinical applications. An update. Immunology, Endocrine \& Metabolic Agents in Medicinal Chemistry, 13(1), 46-59.

[44] Ahmed, R.G., El-Gareib, A.W. 2014.Lactating PTU exposure: I- Alters thyroid-neural axis in neonatal cerebellum. Eur. J. of Biol. and Medical Sci. Res. 2(1), 1-16.

[45] Ahmed, R.G., El-Gareib, A.W., 2017.Maternal carbamazepine alters fetal neuroendocrinecytokines axis. Toxicology 382, 59-66.

[46] Ahmed, R.G., El-Gareib, A.W., Incerpi, S., 2014. Lactating PTU exposure: II- Alters thyroid-axis and prooxidant-antioxidant balance in neonatal cerebellum. Int. Res. J. of Natural Sciences 2(1), 1-20.

[47] Ahmed, R.G.,El-Gareib, A.W., Shaker, H.M., 2018a.Gestational 3,3',4,4',5pentachlorobiphenyl (PCB 126) exposure disrupts fetoplacental unit: Fetal thyroidcytokines dysfunction. Life Sciences 192, 213220.

[48] Ahmed, R.G., Incerpi, S., 2013. Gestational doxorubicin alters fetal thyroid-brain axis. Int. J. Devl. Neuroscience 31, 96-104.

[49] Ahmed, R.G., Incerpi, S., Ahmed, F., Gaber, A., 2013b. The developmental and physiological interactions between free radicals and antioxidant: Effect of environmental pollutants. J. of Natural Sci. Res. 3(13), 74-110.

[50] Ahmed, R.G.,Walaa G.H., Asmaa F.S., 2018b.Suppressive effects of neonatal bisphenol A on the neuroendocrine system. Toxicology and Industrial Health Journal (in press).

[51] Anney, R., Klei, L., Pinto, D., Regan, R., Conroy, J., Magalhaes, T.R., 2010.A genomewide scan for common alleles affecting risk for autism. Hum Mol Genet. 19, 4072-82.

[52] Candelotti, E., De Vito, P., Ahmed, R.G., Luly, P., Davis, P.J., Pedersen, J.Z., Lin, H-Y., Incerpi, I., 2015. Thyroid hormones crosstalk with growth factors: Old facts and new hypotheses. Immun., Endoc.\&Metab. Agents in Med. Chem., 15, 71-85.

[53] Davis, J.D., Podolanczuk, A., Donahue, J.E., Stopa, E., Hennessey, J.V., Luo, L.G., Lim, Y.P., Stern, R.A., 2008. Thyroid hormone levels in the prefrontal cortex of post-mortem 
brains of Alzheimer's disease patients. Curr Aging Sci. 1, 175-81.

[54] De Vito, P., Candelotti, E., Ahmed, R.G., Luly, P., Davis, P.J., Incerpi, S., Pedersen, J.Z., 2015.Role of thyroid hormones in insulin resistance and diabetes. Immun., Endoc.\&Metab. Agents in Med. Chem., 15, 8693.

[55] El-bakry, A.M., El-Ghareeb, A.W.,Ahmed, R.G., 2010.Comparative study of the effects of experimentally-induced hypothyroidism and hyperthyroidism in some brain regions in albino rats. Int. J. Dev. Neurosci. 28, 371-389.

[56] El-Ghareeb, A.A., El-Bakry, A.M., Ahmed, R.G., Gaber, A., 2016.Effects of zinc supplementation in neonatal hypothyroidism and cerebellar distortion induced by maternal carbimazole. Asian Journal of Applied Sciences 4(04), 1030-1040.

[57] Fatemi, S.H., Snow, A.V., Stary, J.M., AraghiNiknam, M., Reutiman, T.J., Lee, S., Brooks, A.I., Pearce, D.A., 2005.Reelin signaling is impaired in autism. Biol Psychiatry 57, 777-87.

[58] Incerpi, S., Hsieh, M-T., Lin, H-Y., Cheng, GY., De Vito, P., Fiore, A.M., Ahmed, R.G., Salvia, R., Candelotti, E., Leone, S., Luly, P., Pedersen, J.Z., Davis, F.B., Davis, P.J., 2014. Thyroid hormone inhibition in L6 myoblasts of IGF-I-mediated glucose uptake and proliferation: new roles for integrin $\alpha v \beta 3$. Am. J. Physiol. Cell Physiol. 307, C150-C161.

[59] King, C.R., 2011. A novel embryological theory of autism causation involving endogenous biochemicals capable of initiating cellular gene transcription: A possible link between twelve autism risk factors and the autism 'epidemic' Med Hypotheses. 2011 Mar 7.

[60] Kirkegaard, C., Faber, J., 1991. Free thyroxine and 3,3',5'-triiodothyronine levels in cerebrospinal fluid in patients with endogenous depression. ActaEndocrinol (Copenh) 124, 16672 .
[61] Melancia, F., Servadio, M., Schiavi, S., Campolongo, P., Giusti-Paiva, A., Trezza, V., 2017. Testing the correlation between experimentally-induced hypothyroidism during pregnancy and autistic-like symptoms in the rat offspring. Behav Brain Res. 321, 113-122.

[62] Miyata, T., Ono, Y., Okamoto, M., Masaoka, M., Sakakibara, A., Kawaguchi, A., Hashimoto, M., Ogawa, M., 2010.Migration, early axonogenesis, and Reelin-dependent layerforming behavior of early/posterior-born Purkinje cells in the developing mouse lateral cerebellum.Neural Dev. 5, 23.

[63] Roman, G.C., 2007. Autism: transient in utero hypothyroxinemia related to maternal flavonoid ingestion during pregnancy and to other environmental antithyroid agents. J Neurol Sci. 262, 15-26.

[64] Rosenberg, R.E., Law, J.K., Yenokyan, G., McGready, J., Kaufmann, W.E., Law, P.A., 2009. Characteristics and concordance of autism spectrum disorders among 277 twin pairs. Arch PediatrAdolesc Med. 163, 907-14.

[65] Sajdel-Sulkowska, E.M., 2010.Oxidative stress and neurotrophin signaling in autism. In: Autism: Oxidative stress, inflammation and immune abnormalities. CRC Press (A Chauhan, V. Chauhan, W.T. Brown, edts) 47-60.

[66] Sampaolo, S., Campos-Barros, A., Mazziotti, G., Carlomagno, S., Sannino, V., Amato, G., Carella, C., Di Iorio, G., 2005. Increased cerebrospinal fluid levels of 3,3',5'triiodothyronine in patients with Alzheimer's disease. J ClinEndocrinolMetab. 90, 198-202.

[67] Van Herck, S.L.J., Geysens, S., Bald, E., Chwatko, G., Delezie, E., Dianati, E., Ahmed, R.G., Darras, V.M., 2013.Maternal transfer of methimazole and effects on thyroid hormone availability in embryonic tissues.Endocrinol. 218, 105-115.

[68] Verhoelst, C.H., Roelens, S.A., Darras, V.M., 2005.Role of spatiotemporal expression of iodothyronine deiodinase proteins in cerebellar cell organization. Brain Res Bull. 67, 196-202.

Citation: Ahmed R.G. Is there a Connection between Maternal Hypothyroidism and Developing Autism Spectrum Disorders?. ARC Journal of Neuroscience. 2018; 3(1):5-8. doi:dx.doi.org/10.20431/2456$057 X .0301002$.

Copyright: (C) 2018 Authors. This is an open-access article distributed under the terms of the Creative Commons Attribution License, which permits unrestricted use, distribution, and reproduction in any medium, provided the original author and source are credited. 